\title{
Juvenile nasopharyngeal angiofibroma
}

\author{
Rohan Kumar Singh, Bhushita B Lakhkar, Prerna Anup Patwa, \\ Gaurav Vedprakash Mishra
}

Radiodiagnosis, Datta Meghe Institute of Medical Sciences - Wardha Campus, Wardha, Maharashtra, India

\section{Correspondence to}

Dr Gaurav Vedprakash Mishra; gaurav.mishra@dmimsu.edu.in

Accepted 10 February 2022

\section{DESCRIPTION}

A 10-year-old boy visited the outpatient department of radiodiagnosis of our institution with complaints of progressive unilateral nasal obstruction, nasal discharge for 3 months and difficulty breathing while sleeping. There was history of epistaxis with $30-40 \mathrm{~mL}$ of blood loss and intermittent headaches relieved with analgesics. The patient was physically well-built with no clinical pallor; however, he breathed through his mouth. An external, non-tender facial deformity was noted as swelling on the right cheek (figure 1A). Endoscopic examination revealed a mass filling most of the right middle and inferior meatus extending up to the choana, showing active serous discharge and tinges of blood clots. The mass was soft and compressible, arising from the right lateral wall. On CT, a soft tissue density lesion was noted in the nasopharynx, right sphenoid sinus and ethmoid air cells, with lateral extension into the right infratemporal fossa through the right sphenopalatine fossa, causing its widening. There was an anterior bulging of the posterior wall of the right maxillary sinus with a decrease in its size (figure 1B). CT scan helps in determining invasion of the cancellous sphenoid bone, tumour staging and treatment planning. Soft tissue extension was determined on contrastenhanced MRI with a large ill-defined, vividly enhancing lesion arising from the right sphenopalatine foramen, causing its widening, with extension into the right infratemporal fossa and masseter space (figure 2A). The lesion was heterogeneously hyperintense on T2/Fluid-attenuated inversion recovery (FLAIR) with a small cystic area and few hypointense foci within, giving a salt and pepper appearance (figure 2B), hypointense on T1, no restriction diffusion on Diffusion weighted imaging (DWI), and a few focal areas of blooming on Gradient-echo sequences (GRE).

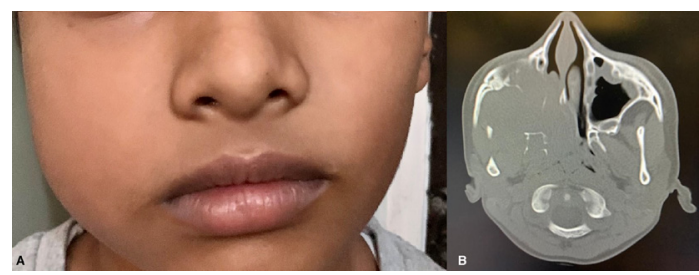

Figure 1 (A) Clinical image showing mild external facial deformity in the form of swelling on the right cheek. (B) CT axial section showing soft tissue density lesion arising from the right sphenopalatine foramen with notable extension into the nasopharynx and adjacent bony destruction.

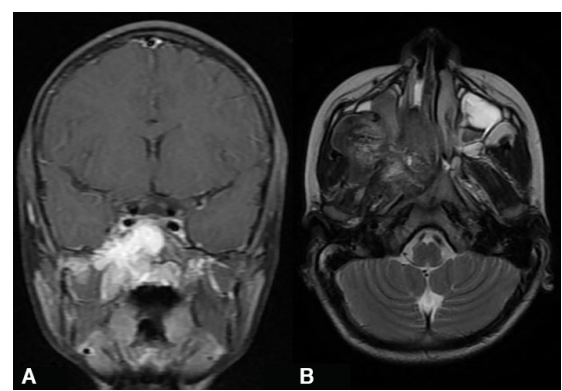

Figure 2 (A) Contrast-enhanced T1-weighted coronal image showing a vividly enhancing lesion in the right maxillary sinus with medial extension and widening of the sphenopalatine fossa. (B) T2-weighted axial image demonstrating anterior bowing of the posterior wall of the right maxillary sinus, resulting in Holman-Miller sign. The lesion is seen extending into the nasal cavity via the infratemporal fossa.

The lesion extended into the posterior nasal cavity and ethmoid sinus, causing erosion of the right nasal cavity turbinate. Anterolaterally, anterior bowing of the posterior wall of the right maxillary sinus was noted, giving the pathognomonic Holman-Miller antral sign (figure 2B). The lesion extended into the right maxillary sinus and infratemporal fossa, causing widening of the pterygomaxillary fissure, with widening of the inferior orbital fissure and abutment of the right optic nerve apex. The superior and inferior extensions were up to the sella and hard palate, respectively, and the clivus posteriorly causing the supracavernous right internal carotid encasement. There was no infiltration into the buccal muscles. After imaging, the patient was referred for superselective embolisation.

Angiofibromas are benign, non-encapsulated lesions occurring in the nasopharynx, predominantly originating near the sphenopalatine foramen. They tend to extend in all directions with multiple projections. Epistaxis, unilateral nasal obstruction, pain and facial deformities are the most common symptoms associated with nasopharyngeal angiofibroma. They show connective tissue stroma with multiple vascular channels on histopathology. ${ }^{1}$ Surgery is required for the management of nasopharyngeal angiofibroma. Endoscopic nasal microsurgery is associated with less postoperative morbidity and blood loss during surgery but is restricted to limited lesions. Large tumours need transpalatal approach with lateral rhinotomy, and preoperative embolisation is performed to reduce intraoperative blood loss. ${ }^{2}$ Although large tumours require open surgery, 


\begin{tabular}{ll}
\hline Table & UPMC staging system for angiofibroma \\
\hline Stage & UPMC staging system \\
\hline I & Nasal cavity, medial pterygopalatine fossa. \\
\hline II & Paranasal sinuses, lateral pterygopalatine fossa; no residual vascularity. \\
III & Skull base erosion, orbit, infratemporal fossa; no residual vascularity. \\
IV & Skull base erosion, orbit, infratemporal fossa; residual vascularity. \\
V & Intracranial extension, residual vascularity; M, medial extension; L, lateral extension. \\
\hline UPMC, University of Pittsburgh Medical Center.
\end{tabular}

\section{Patient's perspective}

I noticed a gradually increasing swelling on the right cheek of my son and he had difficulty in breathing with some foreign body sensation in his nose. We came to the rural hospital for further investigation and management. He was advised magnetic resonance imaging of PNS and orbit and diagnosis of juvenile nasopharyngeal angiofibroma was made. We are referred to a higher centre for further management.

\section{Learning points}

- Clinicians should not be deceived by the size of the tumour as perceived as it can only be the 'tip of the iceberg'.

- Contrast CT aids in diagnosis and allows accurate staging of tumours, which is necessary in order to choose surgical techniques and estimate the prognosis. recent literature suggests that endoscopic endonasal removal can be performed postembolisation, for which the University of Pittsburgh Medical Center staging system is used (table 1). ${ }^{3}$

Contributors RKS: design, concept and major contribution to manuscript preparation. BBL: analysis and interpretation of patient data. PAP: design, concept and contribution to manuscript preparation. GVM: manuscript correction, editing and review. All authors have read and approved the manuscript.

Funding The authors have not declared a specific grant for this research from any funding agency in the public, commercial or not-for-profit sectors.

Competing interests None declared.

Patient consent for publication Parental/guardian consent obtained.

Provenance and peer review Not commissioned; externally peer reviewed.

Case reports provide a valuable learning resource for the scientific community and can indicate areas of interest for future research. They should not be used in isolation to guide treatment choices or public health policy.

\section{ORCID iD}

Gaurav Vedprakash Mishra http://orcid.org/0000-0003-4957-7479

\section{REFERENCES}

1 Pillenahalli Maheshwarappa R, Gupta A, Bansal J, et al. An unusual location of juvenile angiofibroma: a case report and review of the literature. Case Rep Otolaryngol 2013;2013:1-3.

2 Alves FR, Granato L, Maia MS. Surgical approaches to juvenile nasopharyngeal angiofibroma-case report and literature review. Int Arch Otorhinolaryngol 2006;10:162-6.

3 Snyderman $\mathrm{CH}$, Pant $\mathrm{H}$, Carrau RL, et al. A new endoscopic staging system for angiofibromas. Arch Otolaryngol Head Neck Surg 2010;136:588-94.

Copyright 2022 BMJ Publishing Group. All rights reserved. For permission to reuse any of this content visit

https://www.bmj.com/company/products-services/rights-and-licensing/permissions/

BMJ Case Report Fellows may re-use this article for personal use and teaching without any further permission.

Become a Fellow of BMJ Case Reports today and you can:

- Submit as many cases as you like

- Enjoy fast sympathetic peer review and rapid publication of accepted articles

- Access all the published articles

Re-use any of the published material for personal use and teaching without further permission

Customer Service

If you have any further queries about your subscription, please contact our customer services team on +44 (0) 2071111105 or via email at support@bmj.com.

Visit casereports.bmj.com for more articles like this and to become a Fellow 